\title{
Intravascular Coagulation in a Case of Clostridium perfringens Septicaemia : Treatment by Exchange Transfusion and Heparin
}

\author{
M. L. RUBENBERG,* M.D. ; L. R. I. BAKER, $†$ M.B., M.R.C.P. ; J. A. MCBRIDE, $\ddagger$ M.B., M.R.C.P. \\ L. H. SEVITT, $\S$ M.B., M.R.C.P. ; M. C. BRAIN, $\|$ D.M., M.R.C.P.
}

Brit. med. F., 1968, 4, 271-274

Clostridium perfringens ( $\mathrm{Cl}$. welchii) infection following an abortion has always been associated with a very high mortality, of ten as great as $80 \%$ (Toombs and Michaelson, 1928 ; Hill, 1936 ; Russell and Roach, 1939 ; Butler, 1945). Although the use of antibiotics in addition to antitoxin might have been expected to reduce the death rate, the fatality rate recorded by Mahn and Dantuono (1955) differed little from that of previous reports. Immediate hysterectomy (Decker and Hall, 1966), hyperbaric oxygen (Brummelkamp et al., 1963; McAllister et al., 1963; Brummelkamp, 1965), and exchange transfusion (Bessis, 1949 ; Funck-Brentano et al., 1965) have also been used in treatment. The relative merits of these newer forms of treatment have not yet been clearly established.

The case we report presented with massive intravascular haemolysis and anuria, complicating $\mathrm{Cl}$. perfringens septicaemia. It was thought likely that a state of intravascular coagulation was present and that this was being maintained by the release of thromboplastin from toxin-damaged red cells. Therefore, in addition to treatment with antibiotics and antitoxin, an immediate exchange transfusion was performed to remove as many of the damaged red cells as possible, and treatment with heparin was begun so as to stop the intravascular coagulation.

The effect of these measures on intravascular haemolysis, the level of coagulation factors, platelet survival, fibrinogen catabolism, and the level of fibrin degradation products in the serum are presented.

\section{Methods}

Routine haematological procedures were carried out as described by Dacie and Lewis (1963). Platelets were counted by the method of Brecher and Cronkite (1950). Platelet survival was measured by using ${ }^{51} \mathrm{Cr}$-labelled platelets prepared by the method of Morrison and Baldini (1967). Fibrinogen was estimated by the method of Ratnoff and Menzie (1951). Fibrinogen catabolism was measured, using fibrinogen prepared by the method of Regoeczi and Walton (1967) and iodinated by the ${ }^{131}$ I monochloride method of McFarlane (1963). The fractional catabolic rates of fibrinogen and the relative partition of the protein between the intravascular and the extravascular compartments were calculated by the method of Matthews (1957).

Fibrin split products were assayed in the serum by agar-gel immunodiffusion (Ouchterlony, 1958) and by the tanned-redcell haemagglutination inhibition assay, using rabbit anti-human fibrinogen antiserum (Merskey et al., 1966).

Fibrinolysis was assessed by measurement of plasminogen (Alkjaersig et al., 1959), lysis of fibrin plates (Alkjaersig et al., 1959), and euglobulin lysis time (Nilsson and Olow, 1962).

- Special Fellow, USPHS (NIAMD). Present address : Department of Haematology, Maimonides Hospital of Brooklyn, $480210 \mathrm{th}$ Avenue, Brooklyn, New York 11219, U.S.A.

Registrar in Haematology and Medicine.

Senior Registrar in Haematology. In receipt of a grant from Glaxo Ltd. Registrar in Medicine.

Lecturer in Haematology; Consultant Physician.

M.R.C. Group for the Study of Haemolytic Mechanisms, Departments of Haematology and Medicine, Royal Postgraduate Medical School, London W.12.

\section{Case Report}

A 32-year-old woman was admitted to hospital two days after an attempt to procure an abortion, after 12 weeks of amenorrhoea, by using a solution of Dettol (chloroxylenol sol. $5 \%$ ) and water. On the day of admission to another hospital, 1 December 1966, she complained of pain in the lower abdomen and back, developed a foul vaginal discharge, and became oliguric. Her temperature was $100.4^{\circ}$ F. $\left(38^{\circ}\right.$ C.).

Examination of a peripheral blood film and a high vaginal swah 'stained by Gram's method revealed large Gram-positive encapsulated bacilli, and a heavy growth of $\mathrm{Cl}$. perfringens was cultured from both blood and vaginal swab. She was treated immediately with cephaloridine $1 \mathrm{~g}$. six-hourly, as there was a history of penicillin allergy, and gas-gangrene antitoxin 20,000 units intravenously. The next day, 2 December (Day 1), she was pale, jaundiced, and cyanosed, and because of complete anuria was transferred to Hammersmith Hospital.

Clinical Findings.-She was conscious, euphoric, and confused. She was febrile $\left(101^{\circ}\right.$ F.; $38.3^{\circ}$ C.) and hyperpnoeic (respiratory rate 40 ). The skin was a striking mahogany colour and the sclerae were yellow. Her nose and fingers were cold and blue, and diffuse magenta-coloured bruises were present on the left side of the neck and at venepuncture sites. The respiratory system was normal on percussion and on auscultation. The pulse was regular (120 per minute), and the jugular venous pressure was not raised. No cardiac murmurs were heard. Blood pressure was $105 / 55$. There was marked lower abdominal tenderness with guarding. Bowel sounds were present. The vagina contained blood and necrotic material. The size of the uterus was felt to be consistent with a 12-week pregnancy. The optic fundi and cranial nerves were normal. Tendon reflexes were present and equal.

Laboratory Investigations.-Haemoglobin 7.2 g. $/ 100$ ml. ; P.C.V. $26 \%$; M.C.H.C. $27 \%$; reticulocytes $1.0 \%$; white cell count $50,000 /$ cu. mm. (segmented neutrophils $57 \%$, non-segmented neutrophils $23 \%$, metamyelocytes $9 \%$, myelocytes $1 \%$, lymphocytes $7 \%$, eosinophils $1 \%$, monocytes $2 \%$ ) ; nucleated red blood cells 2 per 100 white cells; platelets $88,000 / \mathrm{cu}$. $\mathrm{mm}$. The peripheral blood film showed striking spherocytosis and microspherocytosis of the red cells, fewer than $20 \%$ being normal in appearance (Fig. 1).

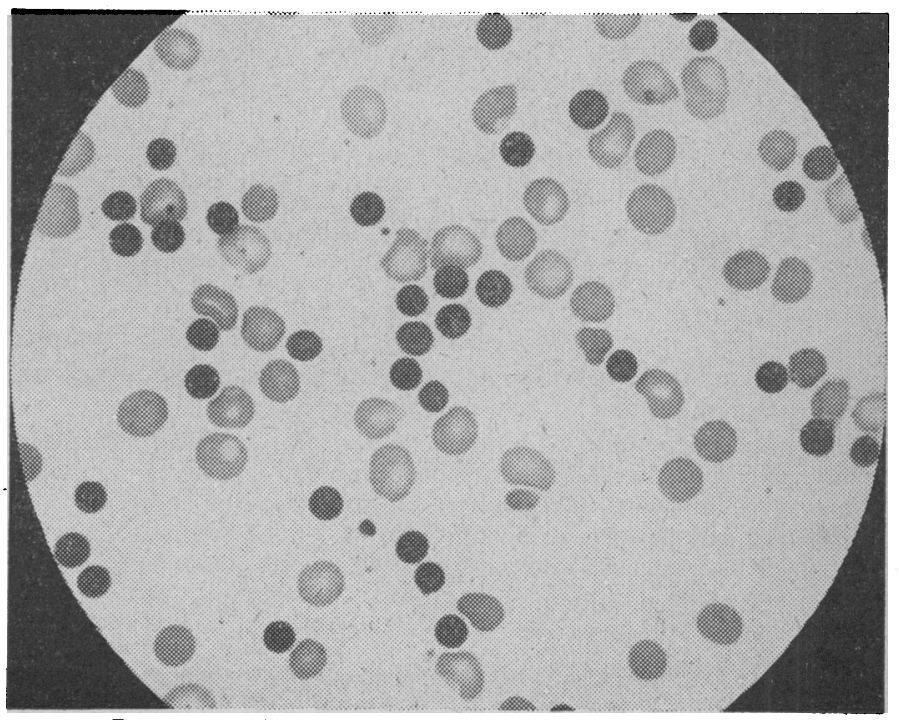

Fig. 1.-Peripheral blood film on admission. $(\times 610$. 
Occasional Howell-Jolly bodies were present in red cells. No Grampositive bacilli were seen. The whole blood clotting-time was 14 minutes. Clot retraction was normal. The plasma fibrinogen was $140 \mathrm{mg} . / 100 \mathrm{ml}$. The level of factor VIII was $8 \%$ of normal. The natient's plasma had antithrombin activity when assayed by serial dilutions of thrombin, and prolonged the thrombin time of normal plasma, indicating the presence of a circulating anticoagulant. No increased fibrinolysis was observed in either whole blood clot or euglobulin clot within five hours, or on a fibrin plate within 18 hours. Plasminogen and activator were present in normal amounts as estimated by use of heated and unheated fibrin plates. Plasminogen was also normal when measured by casein lysis. Fibrin split products were detected in the serum both by immunodiffusion and by the haemagglutination inhibition assay (see Fig. 3). The plasma haemoglobin was $2,200 \mathrm{mg} . / 100 \mathrm{ml}$. Serum electrolytes: sodium 124 , potassium 6.4 , chloride 89 , and bicarbonate $13 \mathrm{mEq} / 1$. ; blood urea $122 \mathrm{mg} . / 100 \mathrm{ml}$.

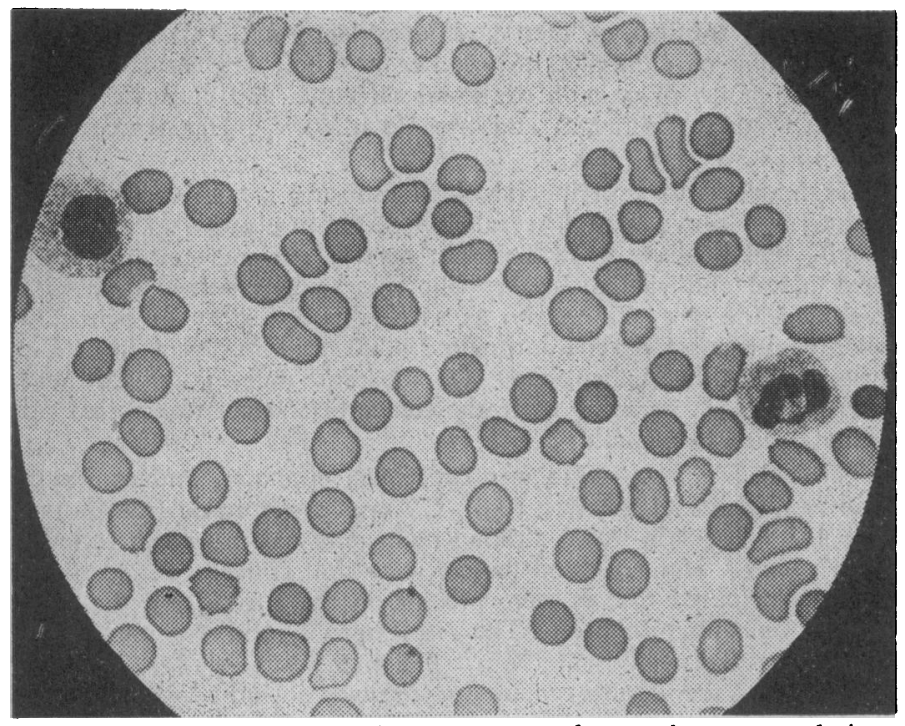

Fig. 2.-Peripheral blood film 10 hours after exchange transfusion. $(\times 610$.

\section{Progress}

Four hours after admission a Scribner shunt was placed between the right radial artery and vein and an exchange transfusion carried out. Nine litres of 18-hour-old bank blood was exchanged within 65 minutes ; 2,000 units of heparin, $150 \mathrm{mg}$. of calcium chloride, and $100 \mathrm{mg}$. of hydrocortisone were added to each $500 \mathrm{ml}$. of blood. The central venous pressure and electrocardiogram remained within normal limits, and the blood pressure did not fall below 95/50 during the exchange transfusion.

There was marked improvement in the patient's condition; the mahogany discoloration of the skin was reduced and the nose and fingers became warmer. This was accompanied by a fall in plasma haemoglobin to $320 \mathrm{mg} . / 100 \mathrm{ml}$, and a reduction in the level of fibrin split products (Fig. 3).

Next morning, 10 hours after the exchange transfusion, the peripheral blood film was nearly normal, with only occasional spherocytes (Fig. 2). The level of factor VIII had risen to $58 \%$ of normal, and the level of fibrinogen was $165 \mathrm{mg} . / 100 \mathrm{ml}$.

Treatment was continued with heparin in a dose of 20,000 units subcutaneously every six hours, erythromycin $300 \mathrm{mg}$. intramuscularly every six hours, cephaloridine $1 \mathrm{~g}$. intravenously every 12 hours, and gas-gangrene antitoxin 30,000 units intravenously every six hours. Oral fluid and dietary protein were restricted.

Fever subsided within 24 hours of admission. On Day 3 bleeding at injection sites and leakage of blood from the arteriovenous fistula occurred. This was attributed to heparin, and the morning dose was halved and the next dose omitted. Protamine sulphate $100 \mathrm{mg}$. was given at noon and a second dose of $85 \mathrm{mg}$. three hours later.

The following morning, 24 hours after stopping heparin and despite giving protamine, the bleeding tendency persisted. The level of fibrin split products had risen again (Fig. 3) and there was a slight fall in fibrinogen concentration. The whole blood clottingtime was 14 minutes and the prothrombin time 14 seconds.
Fibrinogen 7.5 g. was infused and heparin treatment restarted, 20,000 units being given daily by continuous intravenous infusion for the next 10 days. The bleeding lessened, and ceased within three days. The level of fibrin split products fell and the fibrinogen concentration and platelet count rose progressively, to reach peak values at $720 \mathrm{mg} . / 100 \mathrm{ml}$. on the 10th day and greater than $700,000 / \mathrm{cu}$. $\mathrm{mm}$. on the $28 \mathrm{th}$ day respectively (Fig. 4). Haemoglobin levels remained normal and the white cell count returned to normal values within two weeks.

Complete anuria persisted during her first two weeks in hospital. The blood urea was maintained at approximately $100 \mathrm{mg} . / 100 \mathrm{ml}$. by continuous peritoneal dialysis from Day 3 onwards. During the third week she began to pass small amounts of urine, which increased in volume over the next month to reach a daily output of $350 \mathrm{ml}$. The blood urea was kept at about $100 \mathrm{mg} . / 100 \mathrm{ml}$. by peritoneal dialysis at night only.

During the seventh week of her admission she developed signs of consolidation of the lower lobe of the left lung. A heavy growth of Pseudomonas pyocyanea was cultured from the sputum. In spite of treatment with gentamicin $20 \mathrm{mg}$. intramuscularly eighthourly her condition deteriorated and she died on the 48th day of her admission.

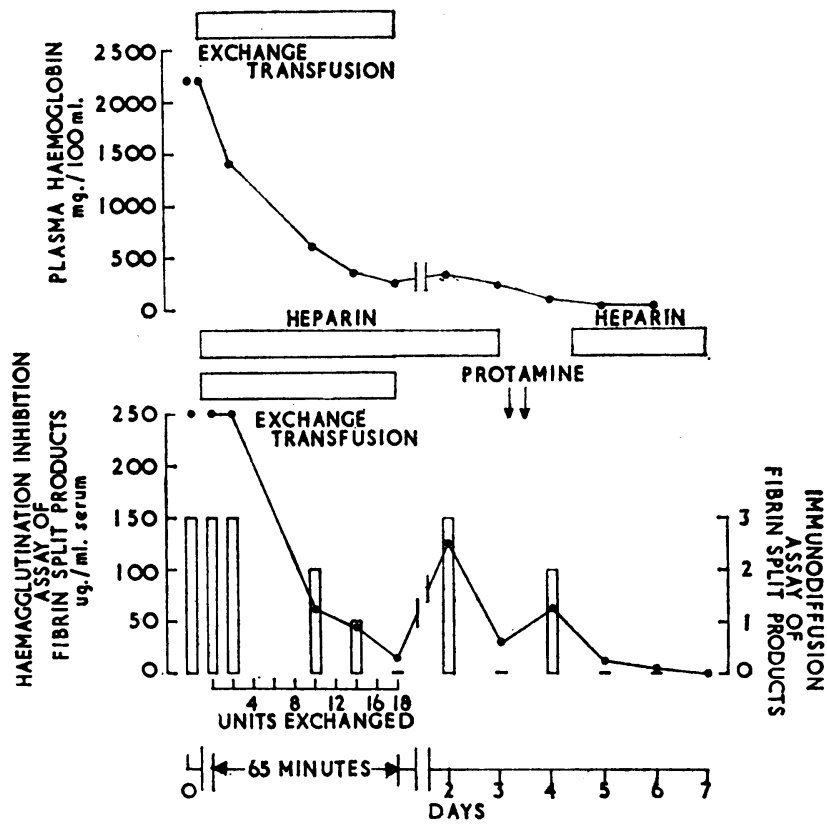

Fig. 3.-Effect of exchange transfusion and heparin treatment on level of plasma haemoglobin and fibrin split products $(\mu \mathrm{g} . / \mathrm{ml}$. of immunological reactive fibrinogen).

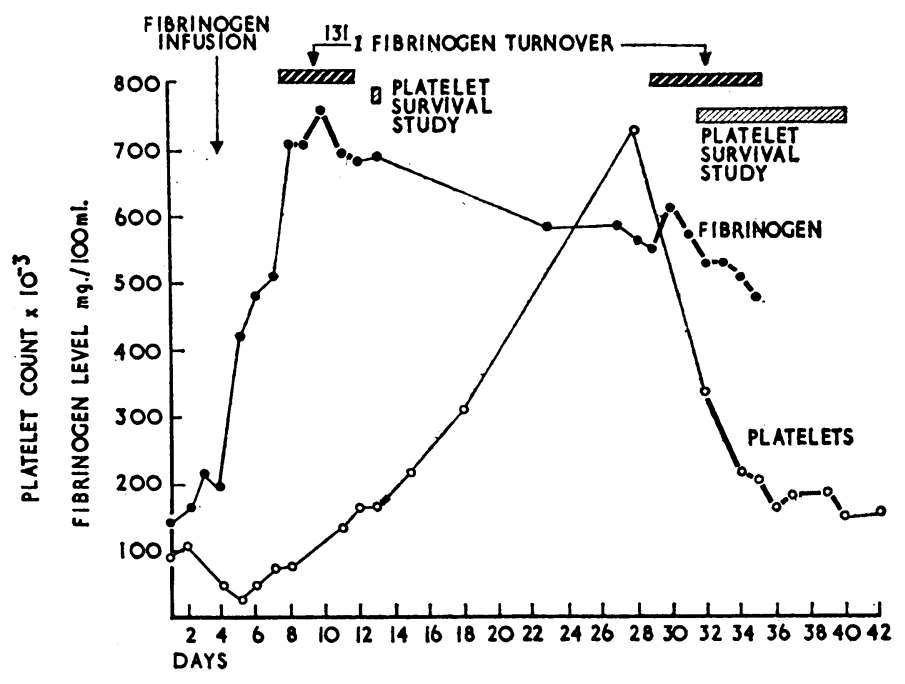

FIG. 4--Level of plasma fibrinogen and of platelet count during patient's illness. The ${ }^{131} \mathrm{I}$-fibrinogen and ${ }^{51} \mathrm{Cr}$-platelet studies are indicated by heavy lines. 


\section{Post-mortem Examination}

This was performed by the coroner's pathologist, Dr. D. A. Pocock, three days after death. There was a large purulent effusion in the left pleural cavity and pus could be expressed from the consolidated lower lobe of the left lung. There was no evidence of pulmonary infarction. The heart was normal except for minimal hypertrophy of the wall of the right ventricle. The peritoneal cavity showed no abnormality. The liver weighed $400 \mathrm{~g}$. and on microscopical examination revealed fatty infiltration and occasional small areas of recent necrosis. The kidneys weighed 235 and $250 \mathrm{~g}$. Microscopical examination showed severe tubular necrosis with numerous pigmented casts. The tubular epithelium showed signs of regeneration and there was no evidence of cortical necrosis. The uterus and adnexae were normal in size and appearance. Minimal signs of inflammation were found on microscopy. There was no evidence of thrombosis of the veins of the pelvis or lower limbs.

\section{Special Haematological Studies}

Iibrinogen Catabolism (Table and Fig. 5).-On Day $4{ }^{131} \mathrm{I}$ labelled fibrinogen from a normal donor was injected. The level of radioactivity fell exponentially during the first four days, despite the rising level of plasma fibrinogen (Fig. 4). The catabolism of fibrinogen has been calculated between Day 8 and 12, when the plasma fibrinogen level was between 695 and $760 \mathrm{mg} . / 100 \mathrm{ml}$. The half-life was 49.5 hours, and the fractional catabolic rate (the total amount of body fibrinogen catabolized daily expressed as a percentage of intravascular pool) was $46.8 \%$. This represents a catabolic rate of $172 \mathrm{mg}$. of fibrinogen per $\mathrm{kg}$. body weight per day. No significant amounts of radioactivity could be recovered in a trichloracetic acid precipitate of peritoneal dialysate. A sample of the same batch of ${ }^{131}$ I-fibrinogen injected into a normal control subject had a half-life of 114.5 hours and a normal catabolic rate. On Day 29 the ${ }^{131}$ I-fibrinogen turnover was re-measured with the use of fibrinogen prepared from the patient's own plasma: the half-life was 65 hours and the fractional catabolic rate normal $(27.3 \%$ per day).

Platelet Survival.-A survival study, using ${ }^{\text {s1 }} \mathrm{Cr}$-labelled platelets obtained from a normal donor, was carried out on Day 13, when the platelet count was $165,000 / \mathrm{cu}$. mm. All the radioactivity disappeared from the blood within one hour and none was detectable

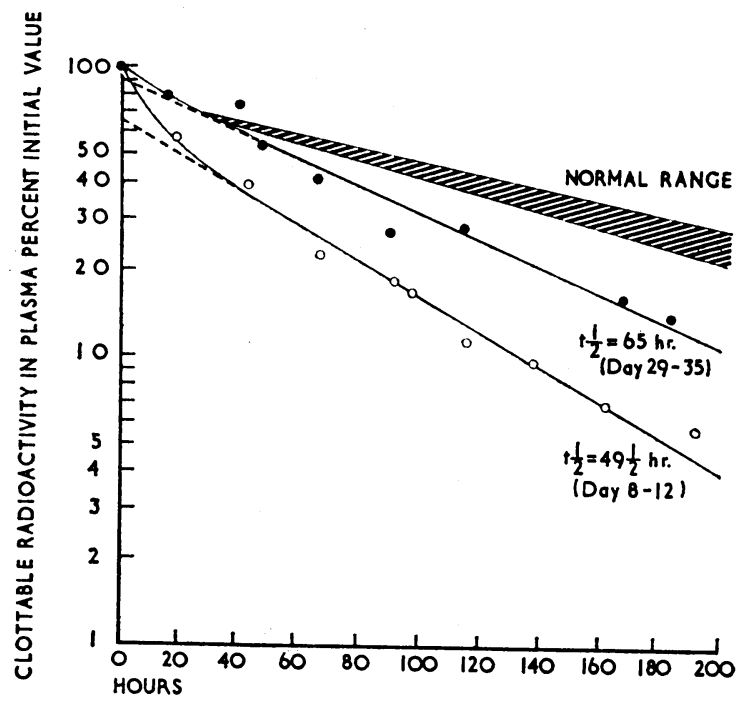

Fig. 5.-Level of ${ }^{181}$ I-fibrinogen in plasma during the two turnover studies. in the circulation during the next four days. The survival was re-estimated by using autologous platelets on Day 32, when the patient's platelet count was $350,000 / \mathrm{cu}$. $\mathrm{mm}$. On this occasion the mean platelet life-span was 134 hours (normal 192-240 hours).

\section{Discussion}

The patient had the classical features of severe clostridial septicaemia: anaemia, haemoglobinaemia, thrombocytopenia, generalized bleeding, and anuria (Isham and Finch, 1956; Muller, 1964 ; Decker and Hall, 1966).

\section{Haemolytic Effect of Clostridial Alpha Toxin}

The haemoglobinaemia was very severe and was associated with marked microspherocytosis of the red cells, probably due to the direct effect of the alpha toxin (lecithinase C) (Macfarlane et al., 1941). Lecithinase C hydrolyses lecithin, a phospholipid component of the red cell membrane. The progressive loss of membrane phospholipid leads to the formation of spherocytes and microspherocytes (Jacob, 1966), possibly by a process of "fragmentation" (Weed and Reed, 1966). Such spherocytes are extremely sensitive to osmotic lysis. Loss of haemoglobin from red cells may also result from holes produced in the red cell membrane by some preparations of $\mathrm{Cl}$. perfringens (Dourmashkin and Rosse, 1966). Lecithinase C also causes hydrolysis of platelet phospholipid, producing lysis, without aggregation, and the release of thromboplastin (platelet factor 3) and thrombocytopenia (Furr et al., 1952). Intravascular coagulation will result from the release into the circulation of thromboplastins derived from both the platelets and the damaged red cells (Quick et al., 1954 ; McKellar and Dacie, 1958 ; Bradlow, 1961 ; Rodriguez-Erdmann, 1965).

\section{Evidence for Intravascular Coagulation}

The low level of factor VIII and fibrinogen and the low platelet count present on admission indicated the consumption of coagulation factors. Further evidence of the occurrence of intravascular coagulation was the presence in the serum of fibrin split products, formed presumably as the result of fibrinolysis of microthrombi. These fibrin split products were probably also responsible for the antithrombin activity in the plasma (Fletcher et al., 1962). The presence of fibrin split products implies activity of fibrinolysis, but the normal whole blood and euglobulin lysis times and the presence of normal levels of activator and plasminogen suggest that the fibrinolysis was restricted to sites where fibrin had been deposited in blood vessels (Pechet, 1965).

Yet further support for the continuance of a state of intravascular coagulation came from the findings of increased fibrinogen catabolism and shortened platelet life-span. The most striking finding in the ${ }^{13}{ }^{1} \mathrm{I}$-fibrinogen studies was the greatly increased fractional catabolic rate of $46.8 \%$ per day in the first study (Day 8-12). This contrasts with our finding of a fractional catabolic rate of $23 \pm 7 \%$ per day in 10 control subjects (Baker et al., 1967). In previous reports of fibrinogen catabolism in patients with elevated levels of fibrinogen and in normal control subjects the fractional catabolic rate has been found to be relatively constant, in keeping with the view that fibrinogen is catabolized as a first-order reaction, the amount

${ }^{131}$ I-fibrinogen Catabolism Calculated by the Method of Matthews (1957). For the First Study (Day 8-12) Fibrinogen was prepared from Plasma Obtained from the Control Subject. For the Second Study (Day 29-35) Fibrinogen was Prepared from Patients Own Plasma

\begin{tabular}{|c|c|c|c|c|c|c|c|c|c|c|c|}
\hline & & \multirow{3}{*}{$\begin{array}{l}\text { Body } \\
\text { Weight } \\
\text { (Kg.) }\end{array}$} & \multirow{2}{*}{\multicolumn{2}{|c|}{ Plasma Volume }} & \multicolumn{4}{|c|}{ Plasma Fibrinogen } & \multicolumn{3}{|c|}{ Catabolic Rate } \\
\hline & & & & & \multicolumn{2}{|c|}{ Pool } & \multirow{2}{*}{$\begin{array}{c}\text { IHalf-life } \\
(\mathrm{Hr} .)\end{array}$} & \multirow{2}{*}{$\begin{array}{c}\text { I.V. } \\
\text { fraction } \\
(\%)\end{array}$} & \multirow{2}{*}{$\% /$ day } & \multirow{2}{*}{ g./day } & \multirow{2}{*}{ mg./kg./day } \\
\hline & & & $\mathrm{ml}$. & ml./kg. & g. & $\mathrm{mg} . / \mathrm{kg}$. & & & & & \\
\hline 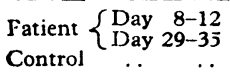 & $\begin{array}{l}\cdots \\
\cdots\end{array}$ & $\begin{array}{l}57 \\
57 \\
70 \cdot 6\end{array}$ & $\begin{array}{l}3,170 \\
3,258 \\
2,693\end{array}$ & $\begin{array}{l}55 \cdot 6 \\
57 \cdot 1 \\
38 \cdot 2\end{array}$ & $\begin{array}{r}22 \cdot 6 \\
18 \cdot 1 \\
6 \cdot 6\end{array}$ & $\begin{array}{l}396 \cdot 5 \\
318 \\
93\end{array}$ & $\begin{array}{c}49 \cdot 5 \\
65 \\
114.5\end{array}$ & $\begin{array}{r}78 \cdot 5 \\
93 \cdot 2 \\
87\end{array}$ & $\begin{array}{l}46 \cdot 8 \\
27 \cdot 3 \\
17 \cdot 0\end{array}$ & $\begin{array}{l}9 \cdot 8 \\
4 \cdot 9 \\
1 \cdot 1\end{array}$ & $\begin{array}{r}172 \\
87 \\
15\end{array}$ \\
\hline
\end{tabular}


catabolized being directly proportional to the size of the fibrinogen pool (McFarlane et al., 1964 ; Regoeczi et al., 1964). Increases in fractional catabolic rate have been observed, however, in five other patients suspected of having intravascular coagulation (Baker et al., 1967). In the second study (Day 29) an increase in the total amount of fibrinogen catabolized was associated with a normal fractional catabolic rate.

The first ${ }^{51} \mathrm{Cr}$-platelet survival with use of normal donor platelets on Day 13, when the platelet count was $165,000 / \mathrm{cu}$. mm., was highly unusual in that no circulating ${ }^{51} \mathrm{Cr}$ was detected one hour after injection. We believe this to be a valid observation, since the only previous occasion on which such a rapid rate of removal of platelets has been observed by us was in another patient with intravascular coagulation and only moderate thrombocytopenia (Brain et al., 1967). The second platelet survival study on Day 32 with use of the patient's own platelets gave a nearly normal survival.

\section{Effect of Exchange Transfusion and Heparin}

The exchange transfusion resulted in a dramatic fall in the levels both of plasma haemoglobin and of fibrin split products; however, 10 hours later the levels of both had risen substantially. This might have been due to a redistribution of free haemoglobin and fibrin split products between the extravascular and intravascular compartments. Alternatively, the reabsorption into the circulation of tissue-bound alpha toxin might have continued to cause red cell damage despite treatment with antitoxin (Furr et al., 1952). The rise in the level of fibrin split products might have been due to the continuing lysis of capillary microthrombi initially present or continuing to be formed.

A further rise in the level of fibrin split products, but not of plasma haemoglobin, occurred when heparin was stopped and protamine was given to neutralize the circulating heparin. These measures did not correct the bleeding state, and in fact resulted in a prolongation of the Quick one-stage prothrombin time and the whole blood clotting-time, and in the reappearance of a circulating antithrombin. These changes suggest that intravascular coagulation was accelerated when heparin was withdrawn. Reintroduction of heparin on Day 4 resulted in the complete disappearance of fibrin split products. within 72 hours. A similar rise in the level of fibrin split products has been reported by Merskey et al. (1964), following the withdrawal of heparin given to a patient with disseminated intravascular coagulation. This observation, too, was interpreted as indicating a recurrence or continuance of intravascular coagulation.

The studies in this patient emphasize the importance of recognizing and treating the intravascular coagulation that may accompany clostridial septicaemia, a complication which would not be influenced by treatment with antibiotics and antitoxin. Though the continuing intravascular coagulation may be controlled with heparin, the presence of large numbers of damaged red cells, which would continue to undergo haemolysis and release thromboplastin, suggests that exchange transfusion may play an important part in the management of the initial stages of this serious condition.

\section{Summary}

A patient who had Clostridium perfringens ( $\mathrm{Cl}$. welchii) septicaemia following a self-induced abortion developed massive intravascular haemolysis, bleeding, and anuria. Approximately $80 \%$ of the red blood cells were spherocytes or microspherocytes. The finding of reduced levels of coagulation factors in the plasma, a low platelet count, and the detection of the products of fibrinolysis (fibrin split products) in the serum indicated the occurrence of disseminated intravascular coagulation. It was thought that this coagulation state would be maintained by the continued release of thromboplastin from the toxin-damaged red cells.

The patient was therefore given an immediate exchange blood transfusion and heparin in addition to conventional management with antitoxin and antibiotics. The exchange transfusion was shown to remove spherocytic red blood cells, free haemoglobin, and fibrin split products from the circulation; it was followed by dramatic clinical improvement.

Subsequent measurements of serum level of fibrin split products, the turnover of ${ }^{131} \mathrm{I}$-fibrinogen, and ${ }^{51} \mathrm{Cr}$-platelet survival suggested that heparin therapy controlled but did not completely prevent the continuation of intravascular coagulation. These studies were repeated during the fourth week, three weeks after heparin had been stopped, and were now normal or nearly so.

The level of blood urea was controlled by peritoneal dialysis, and urine began to be passed in increasing amounts from the third week. The patient, however, developed pneumonia, and, despite treatment with antibiotics, died 48 days after admission.

Exchange transfusion and heparin may play an important part in the management of the initial stages of severe Cl. perfringens infections.

We are grateful to Dr. Oliver Wrong for allowing us to study the patient under his care, to Dr. Sheila Worlledge for her assistance in obtaining the blood for the emergency exchange transfusion, and to Dr. D. A. Pocock for post-mortem specimens. We are indebted to Professor J. V. Dacie for help in the preparation of this paper, and to Misses Marion Scales and Gillian Bolton for their skilled assistance.

\section{REFERENCES}

Alkjaersig, N., Fletcher, A. P., and Sherry, S. (1959). f. clin. Invest., 38, 1086.

Baker, L R. I., Rubenberg, M. L., and Brain, M. C. (1967). In preparation.

Bessis, M. (1949). Blood, 4, 324.

Bradlow, B A. (1961). Brit. f. Haemat., 7, 476.

Brain, M. C., Baker, L. R. I., McBride, J. A., and Rubenberg, M. L. (1967). In press.

Brecher, G., and Cronkite, E. P. (1950). 7. appl. Physiol., 3, 365.

Brummelkamp, W. H. (1965). Ann. N.Y. Acad. Sci., 117, 688.

Brummerema, I., and Hoogendyk, L. (1963). Lancet, 1, 235.

Butler, H. M. (1945). Surg. Gynec. Obstet., 81, 475 .

Dacie, J. V., and Lewis, S. M. (1963). Practical Haematology, 3rd ed. London.

Decker, W. H., and Hall, W. (1966). Amer. F. Obstet. Gynec., 95, 394.

Dourmashkin, R. R., and Rosse, W. F. (1966). Amer. F. Med., 41, 699.

Fletcher, A. P., Alkjaersig. N., and Sherry, S. (1962). f. clin. Invest., 41, 896.

Funck-Brentano, J. L., Jungers, P., and Kochman, S. (1965). Transfusion (Paris), 8, 175 .

Furr, W E., jun., Bourdeau, R. V., Roach, H. D., and Laufman, H. (1952). Surg. Gynec. Obstet., 95, 465.

Hill, A. M. (1936). F. Obstet. Gynaec. Brit. Emp., 43, 201."

Isham, R. L., and Finch, S. C. Med., 41, 734 .

Jacob, H. S. (1966). Amer. F. Med., 41, 734. Lancet, 2, 1040.

McFarlane, A. S. (1963). F. clin. Invest., 42, 346.

Todd, D., and Cromwell. S. (1964). Clin. Sci., 26, 415.

Macfarlane, R." G., Oakley, C. L., and Anderson, C. G. (1941). F. Path. Bact., 52, 99.

McKellar, M., and Dacie, J. V. (1958). Brit. F. Haemat., 4, 404.

Mahn, E., and Dantuono, L. M. (1955). Amer. ₹. Obstet. Gynec., 70, 604 .

Matthews. C. M. E. (1957). Phys. in Med. Biol., 2, 36.
Merskey, C., Johnson, A. J.. Pert. J. H., and Wohl, H. (1964). Blood, 24, 701.

24, 701. Kleiner, G. J., and Johnson. A. J. (1966). Ibid., 28, 1.

Morrison, F. S., and Baldini, M. (1967). Vox Sang. (Basel), 12, 90.

Muller, D. A. (1964). S. Afr med. F., 38, 539.

Nilsson, I M., and Olow. B. (1962). Acta chir. scand., 123, 247.

Ouchterlony, Ö. (1958). Progr. Allergy, 5. 1.

Pechet, L. (1965). New Engl. F. Med., 273, 966.

Pechet, L. (1965). A. J.. Georgatsos, J. G., and Hussey, C. V. (1954). Amer. 7. med. Sci., 228, 207

Ratnoff, O. D., and Menzie, C. (1951). F. Lab. clin. Med., 37, 316.

Regoeczi, E., Regoeczi, G. E., and McFarlane, A. S. (1964).' Pflügers Arch. ges. Physiol., 279. 17

Arch. ges. Phystol., (1967). Thrombos. Diathes. haemorrh. (Stuttg.). In press.

Rodriguez-Frdmann, F. (1965). Blood, 26, 541.

Russell, P. B. iun., and Roach. M. J. (1939). Amer. F. Obstet. Gynec., 38, 437.

Toombs, $P$ W., and Michaelson, I. D. (1928). Ibid., 15, 379.

Weed, R. I., and Reed, C. F. (1966). Amer. F. Med., 41, 681. 